\title{
DRONE MEASUREMENTS OF TEMPERATURE INVERSION Characteristics ANd PARTiculate MatTer Vertical Profiles in Urban EnVironments
}

\author{
Adnan Masic, Boran Pikula, Dzevad Bibic, \\ Vahidin Hadziabdic \& Almir Blazevic
}
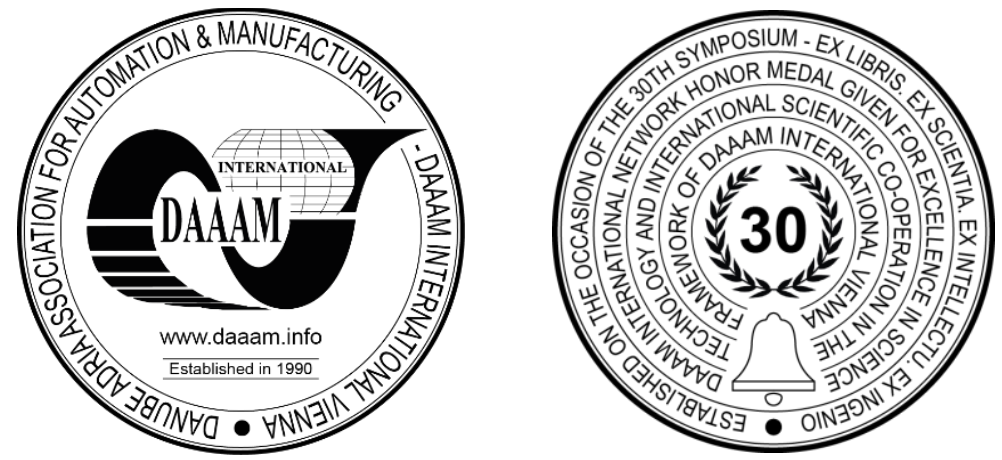

This Publication has to be referred as: Masic, A[dnan]; Pikula, B[oran]; Bibic, D[zevad]; Hadziabdic, V[ahidin] \& Blazevic, A[1mir] (2021). Drone Measurements of Temperature Inversion Characteristics and Particulate Matter Vertical Profiles in Urban Environments, Proceedings of the 32nd DAAAM International Symposium, pp.0123-0126, B. Katalinic (Ed.), Published by DAAAM International, ISBN 978-3-902734-33-4, ISSN 1726-9679, Vienna, Austria DOI: $10.2507 / 32$ nd.daaam.proceedings.018

\begin{abstract}
A new approach for measurements of vertical profiles of temperature and particulate matter (PM) concentrations is developed and tested. Special purpose unmanned aerial vehicle with data acquisition system has been developed in-house. The temperature sensor is based on a fast response thermistor, while the PM sensor uses optical detection of particles. All sensors were tested in the laboratory and calibrated against reference instruments. Two urban locations were selected for field tests. This research produced a very useful asset that characterizes the relation between temperature inversion and air pollution.
\end{abstract}

Keywords: temperature inversion; particulate matter; drone; boundary layer.

\section{Introduction}

Temperature inversion is a natural phenomenon in the atmospheric boundary layer which has strong effects on local climate and air pollution. Understanding temperature inversion plays important role in air quality management. If the temperature inversion is strong enough, natural convection is prevented, and if this happens over an urban area, the concentration of air pollutants rises quickly. Thus, quantitative characteristics of temperature inversion should be regularly investigated to understand and predict air quality in any area prone to temperature inversions, particularly urban valleys.

Quantitative characteristics of the temperature inversion layer may be obtained using various field measurements and observations. Some of the most widely used methods include satellite observations [1], microwave radiometer [2], radiosonde [4]-[7], and drone base measurements [8]-[13]. The novelty in this research is a combination of instruments and conditions: simultaneous measurements of vertical profiles of temperature and particulate matter (PM) concentration in urban environments using an unmanned aerial vehicle (drone). 


\section{The drone and sensors}

An in-house developed drone [14] named MEF-707 was used in this research. It is a medium-sized hexacopter, with a diagonal distance between motors of $707 \mathrm{~mm}$, powered by open-source hardware and software (Figure 1). Major components of MEF-707 are:

- Arducopter open-source flight stack,

- Pixhawk flight controller,

- DJI E800 motors,

- DragonLink long-range radio control system,

- Carbon fiber frame.

Data acquisition system [15] is also in-house developed, and it is called MAQS (Mobile Air Quality System) [16], [17]. It is a modular platform for measurements of various parameters in the atmosphere. The primary application of MAQS is air pollution measurement [18]-[21], but it is expandable with other sensors, including pressure, temperature, relative humidity, carbon dioxide, wind speed, and GNSS coordinates. For the measurements of altitude above ground level (AGL), a barometer was used. A thermistor with a negative coefficient (NTC) was used for temperature measurements. All sensors were calibrated against reference instruments. MAQS system was installed atop of the UAV, in a spot with minimal air turbulence.

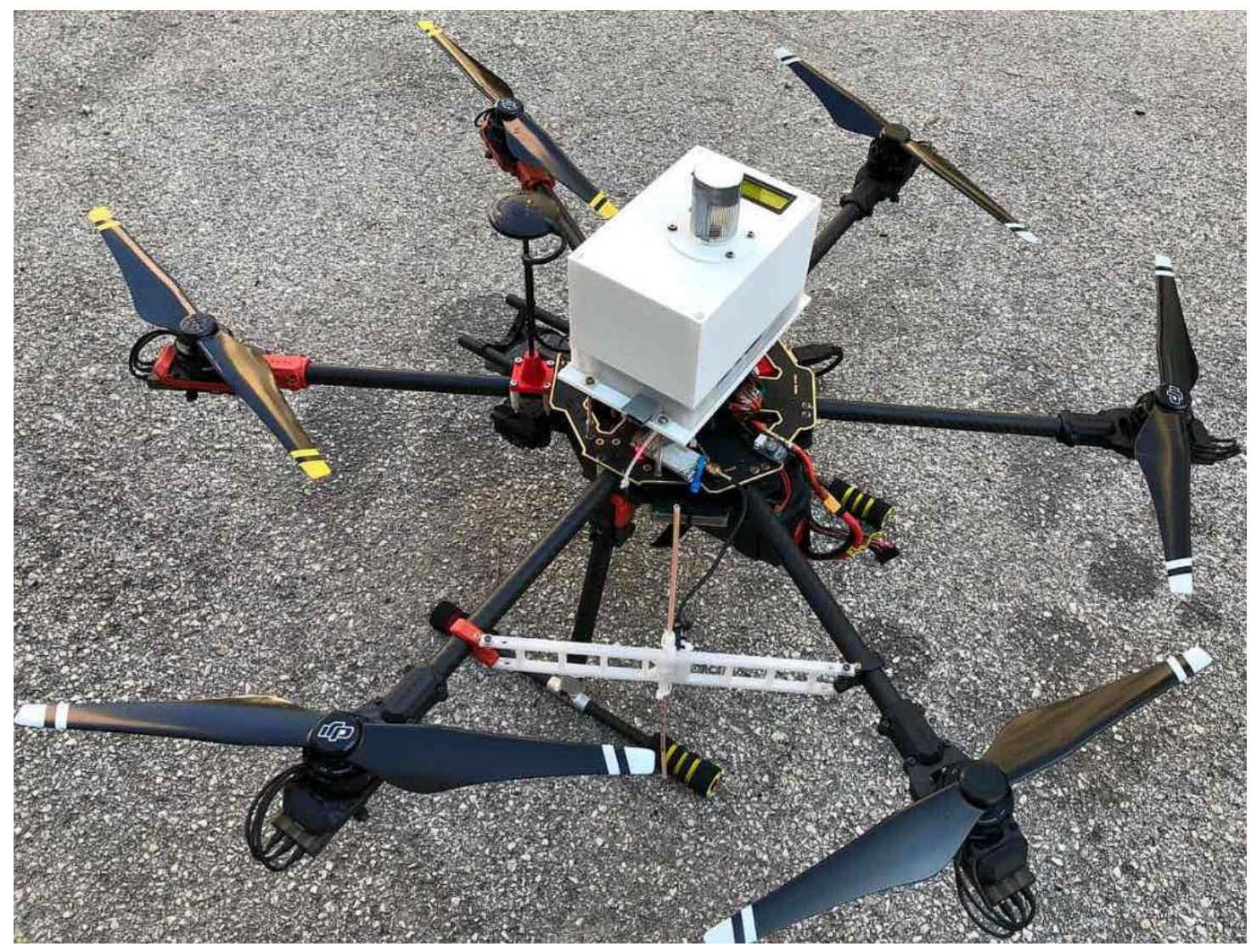

Fig. 1. The MEF-707 drone.

\section{Vertical profiles}

By taking into account the results of our previous campaigns [9] and [13] we were looking for representative test locations for vertical measurements up to $500 \mathrm{~m}$ above ground level. The following locations were selected:

- Hadžići: 43.8210000(N), 18.1961210(E), 562 m ASL,

- Vogošća: 43.8946190(N), 18.3736600(E), 553 m ASL.

Figure 2 shows vertical profiles in Vogošća on 19.01.2021. with strong temperature inversion starting from the ground and very low air temperature. As a consequence, alarmingly high concentrations of $\mathrm{PM}_{2.5}$ were measured on the ground. Temperature inversion appeared at 180m above ground in Hadžići on 02.02.2021. (Figure 3), but the temperature gradient in the inversion layer was moderate and the air pollution level wasn't too high. 

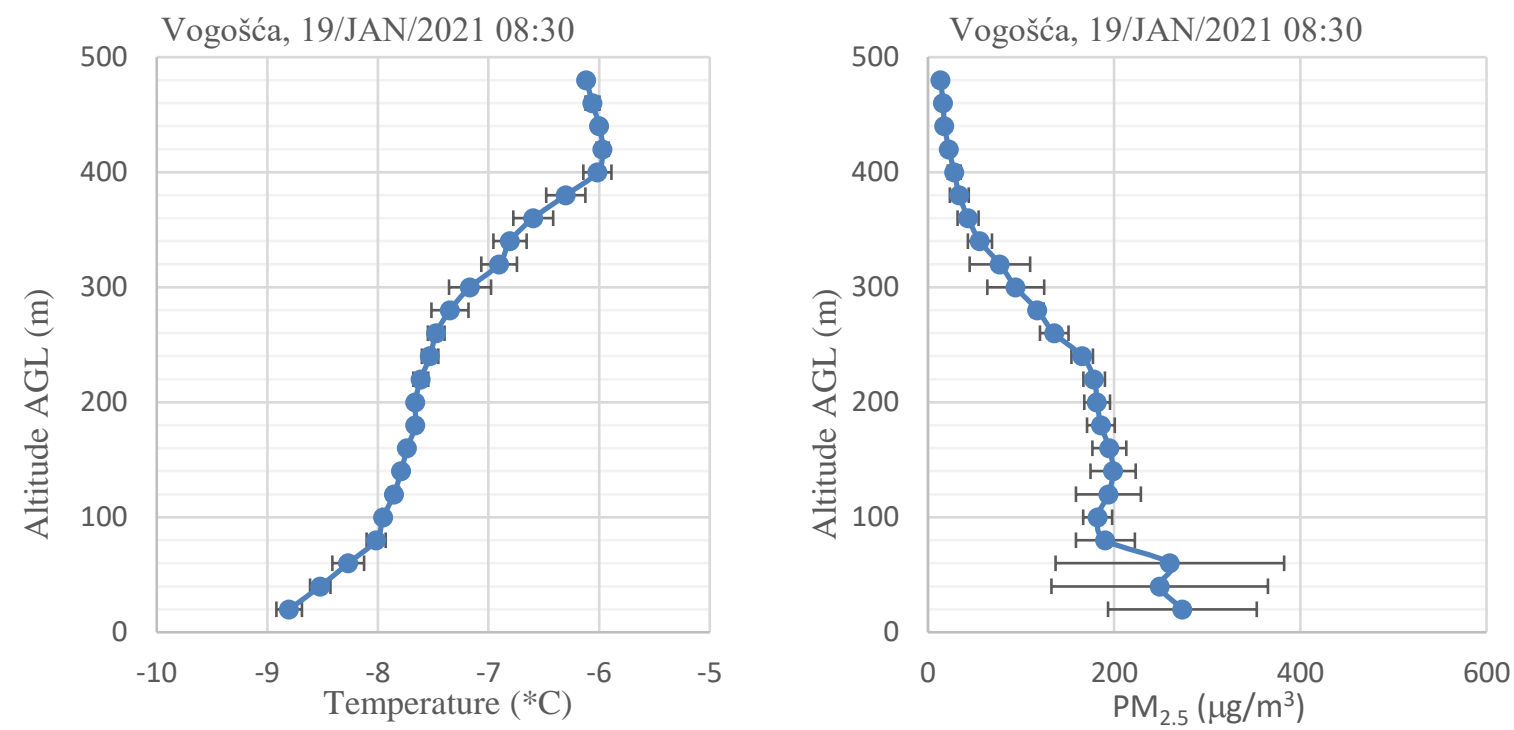

Fig. 2. Vertical profiles in Vogošća.
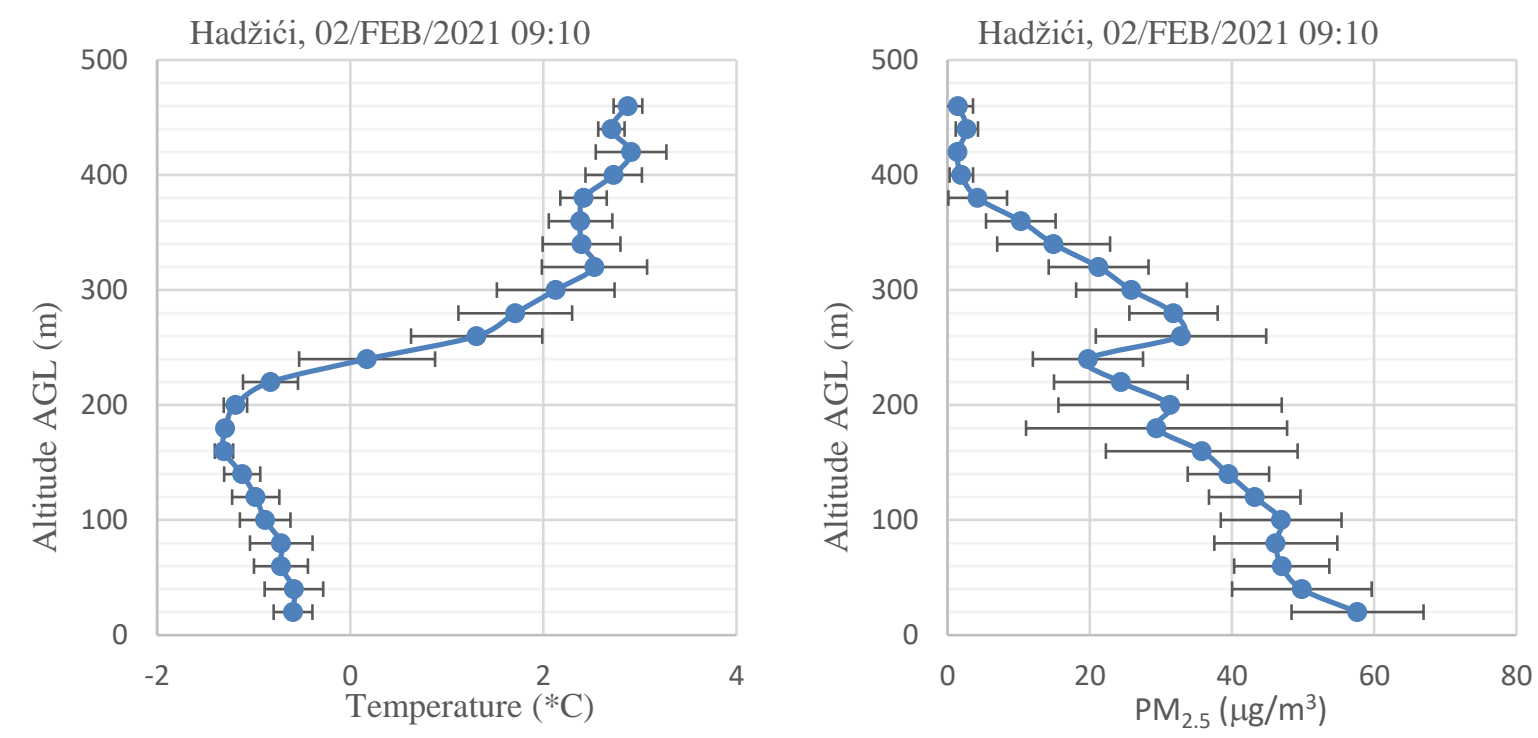

Fig. 3. Vertical profiles in Hadžići.

Figures 2 and 3 show the complexity of the relationship between temperature inversion and air quality. Not every temperature inversion leads to a high concentration of air pollutants. If the gradient in the inversion layer is mild, then natural convection is not prevented completely. But if the temperature inversion gradient is strong and close to the ground, leaving only a shallow atmospheric layer below, this may lead to a dramatic concentration of particulate matter, especially if the ambient air temperature is very low.

\section{Conclusion}

Simultaneous measurements of temperature and $\mathrm{PM}_{2.5}$ were performed using a drone at the different field locations. The results provided evidence of the strong influence of temperature inversion on air pollution in urban environments. An innovative technique based on an in-house developed drone and data acquisition system was used. This platform offers key advantages over other techniques for vertical profiles measurements: low cost per single measurement and full control of flight trajectory and experimental setup in both vertical directions.

Two quantitative characteristics of the temperature inversion layer are particularly important: the height above ground level at which the inversion starts, and the temperature gradient in the inversion layer. As a recommendation for future work, it would be useful to include measurements of concentrations of toxic gasses, such as carbon monoxide and sulfur dioxide. Long-term speaking, the drone-based platform for atmospheric observation and measurements has the potential to change the paradigm of research in this field. 


\section{References}

[1] Boylan, P., Wang, J., Cohn, S. A., Hultberg, T. \& August, T. (2016). Identification and intercomparison of surfacebased inversions over Antarctica from IASI, ERA-Interim, and Concordiasi dropsonde data, Journal of Geophysical Research: Atmospheres, 121, 9089-9104, DOI: 10.1002/2015JD024724

[2] Pietroni, I., Argentini, S. \& Petenko, I. (2014). One Year of Surface-Based Temperature Inversions at Dome C, Antarctica, Boundary-Layer Meteorology, 150, 131-151, DOI: 10.1007/s10546-013-9861-7

[3] Hudson, S. R. \& Brandt, R. E. (2005). A Look at the Surface-Based Temperature Inversion on the Antarctic Plateau, Journal of Climate, 18, 1673-1696, DOI: 10.1175/JCLI3360.1

[4] Bradley, R. S., Keimig, F. T. \& Diaz, H. F. (1993). Recent changes in the North American Arctic boundary layer in winter, Journal of Geophysical Research: Atmospheres, 98, 8851-8858, https://doi.org/10.1029/93JD00311

[5] Lesins, G., Duck, T. J. \& Drummond, J. R. (2010). Climate trends at Eureka in the Canadian high arctic, Atmosphere-Ocean, 48, 59-80, DOI: 10.3137/AO1103

[6] Zhang, Y., Seidel, D. J., Golaz, J.-C., Deser, C., \& Tomas, R. A. (2011). Climatological Characteristics of Arctic and Antarctic Surface-Based Inversions, Journal of Climate, 24, 5167 - 5186, DOI: 10.1175/2011JCLI4004.1

[7] Lesins, G., Duck, T. J. \& Drummond, J. R. (2012). Surface Energy Balance Framework for Arctic Amplification of Climate Change, Journal of Climate, 25, 8277-8288, DOI: 10.1175/JCLI-D-11-00711.1

[8] Cassano, J. J. (2014). Observations of atmospheric boundary layer temperature profiles with a small unmanned aerial vehicle, Antarctic Science, 26, 205-213, DOI: 10.1017/S0954102013000539

[9] Masic, A.; Musemic, R. \& Dzaferovic-Masic, E. (2016). Temperature Inversion Measurements in Sarajevo Valley Using Unmanned Aerial Vehicles, Proceedings of the 27th DAAAM International Symposium, pp.0423-0427, B. Katalinic (Ed.), Published by DAAAM International, ISBN 978-3-902734-08-2, ISSN 1726-9679, Vienna, Austria, DOI: $10.2507 / 27$ th.daaam.proceedings.062

[10] Cassano, J. J., Seefeldt, M.W., Palo, S., Knuth, S. L., Bradley, A. C., Herrman, P. D., Kernebone, P. A. \& Logan, N. J. (2016). Observations of the atmosphere and surface state over Terra Nova Bay, Antarctica, using unmanned aerial systems, Earth System Science Data, 8, 115-126, DOI: 10.5194/essd-8-115-2016

[11] Chabot, D. \& Bird, D. M. (2015). Wildlife research and management methods in the 21st century: Where do unmanned aircraft fit in? Journal of Unmanned Vehicle Systems, 3, 137-155, DOI: 10.1139/juvs-2015-0021

[12] Gaffey, C. \& Bhardwaj, A. (2020). Applications of Unmanned Aerial Vehicles in Cryosphere: Latest Advances and Prospects. Remote Sensing, 12, 948, DOI: 10.3390/rs12060948,

[13] Masic. A.; Bibic, D.; Pikula, B.; Dzaferovic-Masic, E. \& Musemic, R. (2019). Experimental study of temperature inversions above urban area using unmanned aerial vehicle. Thermal Science, Vol. 23, No. 6A, pp. 3327-3338, DOI: 10.2298/TSCI180227250M

[14] Saric I.; Masic A. \& Delic, M. (2021). Hexacopter Design and Analysis. In: Karabegović I. (eds) New Technologies, Development and Application IV. NT 2021. Lecture Notes in Networks and Systems, vol 233. Springer, Cham. DOI: 10.1007/978-3-030-75275-0_9

[15] Masic, A. (2015). Unmanned Aerial Vehicle as Data Acquisition System. Journal of Trends in the Development of Machinery and Associated Technology. Vol. 19, No. 1, 2015, ISSN 2303-4009 (online), p.p. 181-184.

[16] Masic. A.; Bibic, D.; Pikula, B.; Blazevic, A.; Huremovic, J. \& Zero, S. (2020). Evaluation of optical particulate matter sensors under realistic conditions of strong and mild urban pollution. Atmospheric Measurement Techniques, 13, 6427-6443, DOI: 10.5194/amt-13-6427-2020

[17] Masic, A.; Kepnik, G.; Bektesevic, J.; Mehuljic, M.; Saric, I. \& Hadziabdic, V. (2020). The Network of Smart Sensors for Indoor Air Quality Monitoring, Proceedings of the 31st DAAAM International Symposium, pp.02320235, B. Katalinic (Ed.), Published by DAAAM International, ISBN 978-3-902734-29-7, ISSN 1726-9679, Vienna, Austria, DOI: 10.2507/31st.daaam.proceedings.032

[18] Masic, A.; Pikula, B. \& Bibic, D. (2017). Mobile Measurements of Particulate Matter Concentrations in Urban Area, Proceedings of the 28th DAAAM International Symposium, pp.0452-0456, B. Katalinic (Ed.), Published by DAAAM International, ISBN 978-3-902734-11-2, ISSN 1726-9679, Vienna, Austria DOI: 10.2507/28th.daaam.proceedings.063

[19] Masic, A.; Bibic, D.; Pikula, B. \& Razic, F. (2018). New approach of measuring toxic gases concentrations: principle of operation, Proceedings of the 29th DAAAM International Symposium, pp.0882-0887, B. Katalinic (Ed.), Published by DAAAM International, ISBN 978-3-902734-20-4, ISSN 1726-9679, Vienna, Austria, DOI: 10.2507/29th.daaam.proceedings. 127

[20] Masic, A.; Bibic, D. \& Pikula, B. (2019). On the applicability of low-cost sensors for measurements of aerosol concentrations, Proceedings of the 30th DAAAM International Symposium, pp.0452-0456, B. Katalinic (Ed.), Published by DAAAM International, ISBN 978-3-902734-22-8, ISSN 1726-9679, Vienna, Austria DOI: 10.2507/30th.daaam.proceedings.060

[21] Masic, A.; Pikula, B.; Bibic, D.; Musemic, R. \& Halac, A. (2018). Calibration and Assessment of Low-cost Dust sensors, Proceedings of the 29th DAAAM International Symposium, pp. 523-528, B. Katalinic (Ed.), Published by DAAAM International, ISBN 978-3-902734-xx-X, ISSN 1726-9679, Vienna, Austria, DOI: 10.2507/29th.daaam.proceedings.075 